\title{
Immunomanipulation of Appetite and Body Temperature through the Functional Mimicry of Leptin
}

\author{
Brant A. De Fanti, Fermin I. Milagro, Oscar Lamas, Eduardo Martínez-Ansó, and J. Alfredo Martínez
}

\begin{abstract}
DE FANTI, BRANT A., FERMIN I. MILAGRO, OSCAR LAMAS, EDUARDO MARTÍNEZ-ANSÓ, AND J. ALFREDO MARTÍNEZ. Immunomanipulation of appetite and body temperature through the functional mimicry of leptin. Obes Res. 2002;10:833-837.

Objective: Although current obesity therapies produce some benefits, there is a need for new strategies to treat obesity. A novel proposal is the use of anti-idiotypic antibodies as surrogate ligands or hormones. These anti-idiotypic antibodies carry an internal motif that imitates or mimics an epitope in the antigen (i.e., hormone or ligand). Thus, antiidiotypic antibodies to several ligands may mimic them in transducing signals when binding to their receptors.

Research Methods and Procedures: We developed an antiidiotypic polyclonal antibody against the region of a leptin monoclonal antibody that competitively binds leptin, mimicking the active site structure of leptin. To test whether our anti-idiotype could also reproduce leptin functions, we examined food intake, body weight, and colonic temperature in male Wistar rats $(n=9)$ in response to intracerebroventricular administration of the leptin anti-idiotype.

Results: Our leptin anti-idiotype induced a significant reduction in food intake coupled with an increase in body temperature comparable to that of leptin. That is, the intracerebroventricular administration of $8.0 \mu \mathrm{g}$ of leptin antiidiotype or $5.0 \mu \mathrm{g}$ leptin significantly increased colonic temperature $\left(\Delta 1.9 \pm 0.11{ }^{\circ} \mathrm{C}\right.$ and $\Delta 1.7 \pm 0.12{ }^{\circ} \mathrm{C}$, respectively). In addition, both decreased 24-hour food intake $(-26.4 \pm 2.4 \%$ and $-21.9 \pm 2.2 \%)$ compared with the control. The gain in body weight was also decreased by
\end{abstract}

Received for review October 10, 2001

Accepted for publication in final form March 26, 2002.

Department of Physiology and Nutrition, University of Navarra, Pamplona, Spain.

Address correspondence to Dr. J. Alfredo Martínez, Fisiología y Nutrición, Universidad de

Navarra, c/Irunlarrea 31008, Pamplona, Spain.

E-mail: jalfmtz@unav.es

Copyright (c) 2002 NAASO acute administration of the anti-idiotype $(-1.4 \pm 0.28 \%)$ and leptin $(-1.1 \pm 0.17 \%)$ vs. the phosphate-buffered saline control $(1.3 \pm 0.15 \%)$.

Discussion: These studies revealed that the leptin antiidiotype inhibited food intake and enhanced heat production, mimicking leptin's central actions.

Key words: energy balance, energy expenditure, antiobesity, immunotherapy, anti-idiotypic antibodies

\section{Introduction}

Obesity is the result of a chronic imbalance between energy intake and energy expenditure and can be a function of elevated energy intake or reduced energy metabolism or both (1). Although current pharmacological therapies produce some benefits, new approaches to obesity treatment need to be developed.

A novel proposal is the use or induction of anti-idiotypic antibodies as surrogate ligands or hormones. These antibodies carry an internal image of an epitope of the external antigen (i.e., hormone or ligand) (2) and anti-idiotypic antibodies have been produced to mimic hormones or ligands in transducing signals when binding to their receptors (3). Anti-idiotypic antibodies have been tested in therapeutic immunizations against several autoimmune diseases and cancer (4) and insulin-developed anti-idiotype antibodies reproduced some of the hormone effects, such as enhancing glucose uptake into adipocytes (5).

We developed an antibody (anti-idiotypic antibody) against an antibody that competitively binds leptin, potentially mimicking a leptin-active site $(6,7)$. Leptin is an adipocyte-derived peptide hormone that is secreted in proportion to body fat levels (8), and by suppressing food intake and increasing energy expenditure, leptin serves as the mediator of an adipose tissue-brain endocrine axis for the regulation of energy balance (9). Although exogenous leptin administration to some obese rodent models decreases food intake, increases energy expenditure, and re- 
sults in a reduction in body weight $(10,11)$, most human obesity is accompanied by elevated leptin levels (12), suggesting a peripheral resistance to leptin. There is evidence, however, that exogenous leptin induces weight loss in some obese subjects with elevated endogenous serum leptin concentrations (13), whereas a percentage (5\% to $25 \%$ ) of obese humans has been found to have low to normal plasma leptin levels $(12,14,15)$. Leptin administration may also help those individuals following a weight-reducing program in which leptin levels are reduced in the process (16). Moreover, it may also be advantageous for the small population of obese individuals with leptin deficiency (17), warranting additional research into leptin's potential role in the treatment of human obesity.

To test whether our anti-idiotypic antibody with structural similarity to a leptin-active site could also mimic the function of leptin, we examined food intake, body weight, and colonic temperature in male Wistar rats in response to intracerebroventricular (ICV) administration of the leptin anti-idiotype.

\section{Research Methods and Procedures}

\section{Animals}

Adult male Wistar rats $(n=10 ; 250-325 \mathrm{~g}$ with a mean of $285 \pm 8$ ) from Harlan-Teklad (Barcelona, Spain) were individually housed in suspended metabolic cages in a temperature-controlled room $\left(23 \pm 1{ }^{\circ} \mathrm{C}\right)$ on a 12:12-hour light-dark schedule (lights on at 8:00 AM). Unless otherwise specified, rats had free access to ground rat chow (HarlanTeklad) and water at all times. All procedures were performed according to the international and institutional guidelines of the Animal Care and Use Committee at the University of Navarra.

\section{Surgery}

The rats were anesthetized with $75 \mathrm{mg} / \mathrm{kg}$ of a ketamine $\mathrm{HCl}$ plus $10 \mathrm{mg} / \mathrm{kg}$ xylazine and placed in a stereotaxic instrument (Kopf Instruments, Tujunga, CA). A 24-gauge guide cannula (316GC; Plastics One, Roanoke, VA) was implanted into the right lateral cerebroventricle and anchored to the skull with three stainless steel machine screws (Small Parts, Miami Lakes, FL) and cranioplastic cement (Dentsply, Detrey). The stereotaxic coordinates used were: AP, $-0.8 \mathrm{~mm}$, ML, $1.2 \mathrm{~mm}$ with respect to bregma, and $\mathrm{DV},-3.5 \mathrm{~mm}$ from the skull surface (18). A 31-gauge stylet (316DC; Plastics One) kept the guide cannula clear when the rat was not receiving injections. A recovery period after surgery extended 1 week before rats were subjected to an angiotensin II (ANG II) drinking test. ANG II (Sigma, St. Louis, MO) was dissolved in sterile phosphate-buffered saline + calcium $(\mathrm{PBS}+)$ at a concentration of $20 \mathrm{ng} / \mu \mathrm{L}$. An increased drinking response of at least $3 \mathrm{~mL}$ of water within 20 minutes after an ICV injection of $100 \mathrm{ng}$ ANG II supported correct cannula placement. The ANG II drinking test was repeated before each experiment and at the completion of the study a methylene blue solution was injected into the ventricle, and the brain was extracted from the skull. Cannula placement was confirmed by the appearance of dye in the ventricular system.

\section{Monoclonal Antibody Production}

To raise monoclonal antibodies, adult BALB/c mice were administered with $30 \mu \mathrm{g}$ synthetic rat leptin peptide with amino acid sequence AFSKSCSLPQTRGLQKPESL from the active center along with a T-cell determinant peptide with amino acid sequence FISEAIIHVLHRS named FISEA (19). Both peptides were dissolved in $100 \mu \mathrm{L}$ of PBS (10 $\mathrm{mM}$ phosphate buffer [pH 7.4], $150 \mathrm{mM} \mathrm{NaCl}$ ), and homogenized with $100 \mu \mathrm{L}$ of Freund's complete adjuvant. Mice were boosted twice at 1-month intervals with the same immunogen homogenized in Freund's incomplete adjuvant. Fifteen days after the last immunization, one mouse (selected on the basis of enzyme-linked immunosorbent assay [ELISA] results) received an intravenous injection of $30 \mu \mathrm{g}$ leptin in $200 \mu \mathrm{L} \mathrm{PBS}$, and 3 days later hybridomas were produced by fusion of NS-1 cells with spleen cells, essentially as previously described (20). One monoclonal antileptin antibody, termed $3 \mathrm{H} 10\left(\mathrm{IgG}_{3}\right)$ produced by hybridoma culture, was selected and purified from culture harvest by cell separation and protein A affinity chromatography. Hybrid clones were characterized by immunoblot of whole mouse recombinant leptin (Peprotech EC, London, UK) as well as by an indirect ELISA coated with $0.1 \mu \mathrm{g}$ leptin/well or 30 different leptin synthetic peptides to characterize the specificity of antibodies. The indirect ELISA and the immunoglobulin class determination were performed by standard methodology.

\section{Production of the Anti-idiotypic Antibody (anti-3H10)}

Three male Wistar rats were immunized with purified mouse monoclonal antibody $3 \mathrm{H} 10$. A selected rat received five inoculations at 21-day intervals, the first in Freund's complete adjuvant and four additional injections in Freund's incomplete adjuvant. Serum was collected and IgG fraction purified by means of affinity chromatography on a HiTrap protein G column (Amersham Pharmacia, Barcelona, Spain). Buffer exchange for affinity purification was made on a PD-10 column (Amersham Pharmacia).

To demonstrate anti-Id Ab specificity, rat antiserum prepared against $3 \mathrm{H} 10$ was tested in an ELISA in which the antigen, in this case purified $3 \mathrm{H} 10$, was coating the plate. Thus, when both leptin ( $1 \mu \mathrm{g} /$ well) and rat antiserum serial double dilutions were coincubated, there was clearly a significant binding inhibition when comparing the titer/absorbance observed with the antiserum alone. To neutralize anti-isotypic and anti-allotypic antibodies present in the rat antiserum, a 2-hour preincubation at RT with normal mouse 
serum was made just before using the antiserum in the ELISA. Rat normal serum was used as a negative control.

\section{Experimental Protocol}

Three treatments were randomly assigned to the ICV cannulated rats that responded positively to ANG II. The treatments were $0(\mathrm{PBS}+), 5.0 \mu \mathrm{g}$ leptin, and $8.0 \mu \mathrm{g}$ anti-idiotype injected into the lateral ventricle. Each rat randomly received one of the treatments on a given day followed by 2 days of recovery. For the food intake study, each treatment was given twice, rotating in a counterbalanced order. All injections were performed 2 hours after the beginning of the light cycle (between 10:00 and 11:00 AM). Food cups were removed from the rat cages at 9:00 AM. At 10:00 AM, rats were injected in the lateral ventricle with either $4 \mu \mathrm{L}$ of sterile PBS + or an equal volume of recombinant rat leptin (R\&D Systems, Minneapolis, MN) or antiidiotype in PBS + using an injector cannula (C316I; Plastics One) attached by polyethylene tubing (PE-10) to a $25-\mu \mathrm{L}$ glass Hamilton syringe. For each trial, infusate was delivered, with a CMA/100 pump (CMA/Microdialysis) at 1.0 $\mu \mathrm{L} / \mathrm{min}$, after which the injector cannula was left in place for an additional 1 minute to allow for diffusion away from injection site, before being replaced by the stylet.

Body weight and food intake were measured immediately before injection. The food cups were refilled and reweighed 22 hours later. Food spillage was weighed and the papers lining the chamber floor were changed. Colonic temperature was measured using a petroleum jelly covered YSI 400 series rectal probe thermocouple thermometer (Panlab S.L., Barcelona, Spain) inserted a standardized distance $(6 \mathrm{~cm})$ until a stable temperature reading was obtained. Baseline temperature was measured over 60 minutes before administration of experimental treatments and every 30 minutes over 300 minutes of post-treatment. To eliminate stressrelated elevations in temperature, rats were previously habituated to the rectal probe insertion ( 1 week after the food intake study).

\section{Statistical Analyses}

Data are shown as means \pm SEM. When two means were compared, we used the Student's $t$ test. Comparisons of more than two means were analyzed by two-way ANOVA. Fisher's Protected Least Significance Difference test was used for comparisons between some specific means. A value of $p<0.05$ was considered statistically significant.

\section{Results}

Figure 1 summarizes the responses of ICV leptin, antiidiotype and PBS + on food intake. PBS +-treated rats consumed $17.7 \pm 0.6 \mathrm{~g}$ food over the 22 hours after microinjection at 10:00 AM. Administration of $5.0 \mu \mathrm{g}$ leptin inhibited food intake by $22 \%(p<0.05)$, whereas $8.0 \mu \mathrm{g}$

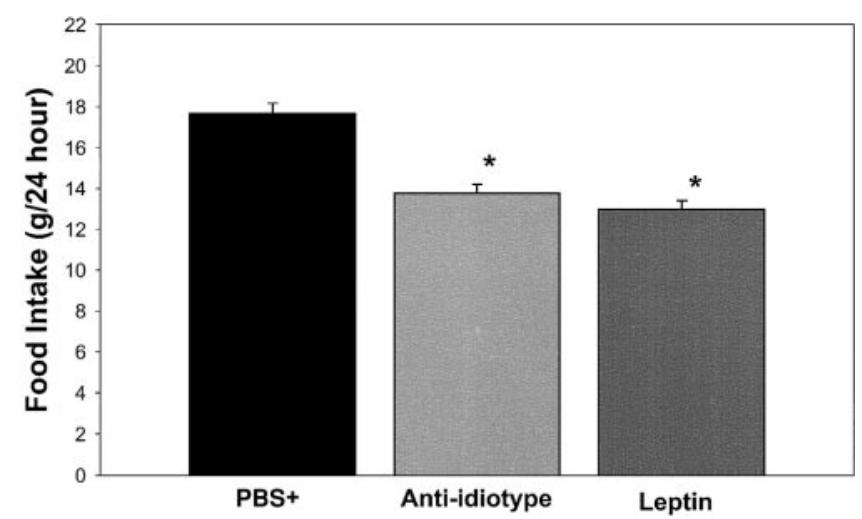

Figure 1: Effects of central leptin/anti-idiotypic antibody on food intake in male Wistar rats $(n=10)$. Mean food intake (g) 24 hours after ICV administration of $5.0 \mu \mathrm{g}$ leptin, $8.0 \mu \mathrm{g}$ anti-idiotype, or $\mathrm{PBS}+$. Rats were used as their own controls and values are expressed as means \pm SEM. *, denotes significant difference from PBS $(p<0.05)$.

anti-idiotype attenuated consumption by $26 \%(p<0.05)$ compared with PBS-treated rats. The gain in body weight (Figure 2) was also decreased by anti-idiotype $(-1.4 \%)$ and leptin $(-1.1 \%)$ vs. the PBS control $(+1.3 \%)$.

The colonic temperatures of PBS +-treated rats remained between 37.4 and $37.8^{\circ} \mathrm{C}$ for the 5 hours recorded after the injection (Figure 3). The ICV administration of $8.0 \mu \mathrm{g}$ of leptin anti-idiotype or $5.0 \mu \mathrm{g}$ leptin significantly increased colonic temperature $\left(\Delta 1.9 \pm 0.11^{\circ} \mathrm{C}\right.$ and $\Delta 1.7 \pm 0.12{ }^{\circ} \mathrm{C}$, respectively), which remained elevated throughout the recording period. To test whether the observed effect of anti-idiotype on colonic temperature was caused by random/ nonspecific antibody binding, we performed a control test with a nonimmunospecific antibody. Central administration of this antibody failed to affect colonic temperature (data not shown).

\section{Discussion}

Antibodies directed against antigenic determinants on another antibody's variable domain, or idiotope, are called anti-idiotypic antibodies. As this region forms the antigenbinding site, in some cases these anti-idiotypic antibodies carry an image of the original antigen (2). If the original antigen is a hormone or ligand, in our case leptin, the structural similarity (i.e., internal image) lends for the possibility that the anti-idiotypic antibody can also functionally mimic the physiological properties of the ligand and bind to cellular receptors. Immunomanipulation, therefore, represents a novel approach to disease treatment with some animal trials yielding promising results. The use of a growth hormone (GH) anti-idiotype promoted growth in GH-deficient rats (21), whereas antibodies against adipocytes seem to be effective in the treatment of diet-induced obese rats (22). 


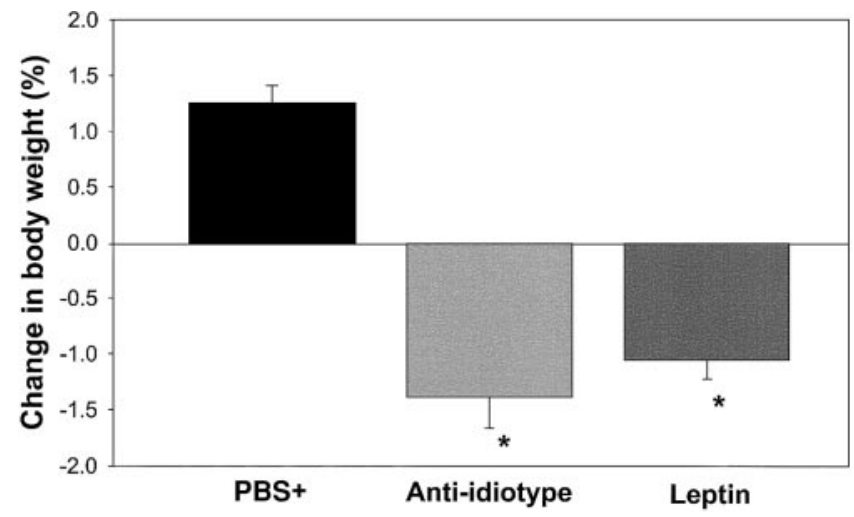

Figure 2: Effects of central leptin/anti-idiotypic antibody on body weight in male Wistar rats $(n=10)$. The percentage change in body weight 22 hours after intracerebroventricular administration of $5.0 \mu \mathrm{g}$ leptin, $8.0 \mu \mathrm{g}$ anti-idiotype, or PBS + . Rats were used as their own controls and values are expressed as means \pm SEM. *, denotes significant difference from PBS $+(p<0.05)$.

Our results demonstrate an anti-idiotype-induced reduction in food intake coupled with an increase in heat production comparable to the effects of leptin. Synthesized primarily by adipose tissue (23), leptin is an important regulator of appetite and energy expenditure through its feedback effects on the brain. Released into the circulation in proportion to body fat mass (8), leptin enters the brain and acts on hypothalamic sites to inhibit energy intake and enhance energy metabolism $(24,25)$. Alterations in leptin production or sensitivity have been suggested to play a role in the pathogenesis of obesity (26), and exogenous leptin is highly effective at reversing obesity in animals that lack functional leptin (10). Although obesity in humans and in most rodent models is usually associated with high circulating leptin levels and peripheral leptin resistance $(12,14)$, recent evidence suggests that up to $25 \%$ of obese individuals have low leptin levels and may benefit from leptin treatment (15). In addition, circulating leptin levels drop after dietary manipulations that result in weight loss and seem to contribute to hunger sensations (16) and weight regain. A leptin antiidiotype may be useful in these circumstances in which leptin replacement would be beneficial. Although exogenous leptin could achieve the same desired effects, use of immunotherapy could allow subjects to generate their own leptin, requiring only occasional priming rather than daily injections. Therefore, a potential strategy based on leptin anti-idiotypes may prove advantageous in the maintenance of leptin levels and prevent the rebound effect.

Although the theoretical basis for immunotherapy is wellfounded, it is important to point out that an antibodyvaccine is no magic bullet. The therapeutic use of antibodies as vaccines remains difficult because of the response against the therapeutic agent. That is, antigen presentation often results in tolerance induction to the antigens contained within the vaccine. Although genetic engineering can be used to reduce the immunogenicity of rodent antibodies, even these humanized antibodies leave open the chance for anti-globulin responses and neutralization on repeated therapy (27).

A more realistic use of the leptin anti-idiotype may be as a probe in both functional and biochemical studies of the leptin receptor. The behavioral and metabolic effects after brain administration suggest that leptin anti-idiotype can act on neuronal networks that control feeding and energy balance. Development of new drugs in this therapeutic area requires an enhanced understanding of the neuroanatomy and neurophysiology underlying the various components of the appetite regulation and energy expenditure in the brain. The ongoing characterization of leptin neurobiology has provided evidence for a specific, saturable transport system for leptin to cross the blood-brain barrier and enter the brains of rodents and humans (28). The reduced entry of leptin into the brain may be one of the mechanisms of resistance in those obese individuals with elevated plasma leptin levels. Thus, the leptin anti-idiotype, serving to map the active sites, may facilitate receptor-based studies and provide a molecular mechanism to account for the dysfunction. In addition, because leptin is a pleitropic hormone, anti-idiotypes may mimic individual functions, allowing for the study of separate systems.

These studies demonstrate that the central administration of a leptin anti-idiotypic antibody inhibited food intake and enhanced heat production, mimicking leptin's central actions. Obesity is an increasingly prevalent and important health problem and although treatment is available, sustained significant weight loss (5 to $10 \%$ of initial body weight) is rare, highlighting the urgent need for effective

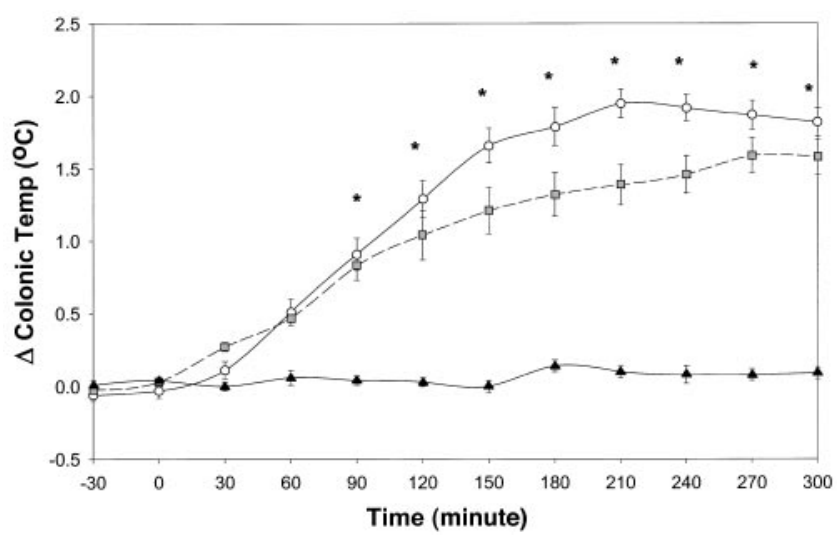

Figure 3: Effects of central leptin/anti-idiotypic antibody on body temperature in male Wistar rats $(n=9)$. Mean colonic temperature 1 hour before and 5 hours after intracerebroventricular administration of $5.0 \mu \mathrm{g}$ leptin $(\square), 8.0 \mu \mathrm{g}$ anti-idiotype $(\bigcirc)$, or PBS $+(\mathbf{\Delta})$. Rats were used as their own controls and values are expressed as means \pm SEM. $*$, denotes significant difference from PBS + $(p<0.05)$. 
new approaches. Despite rapid strides toward an ideal antiobesity drug, additional progress is needed to incorporate new findings in the neurobiology of energy balance into clinical interventions. The characterization of obesity-associated gene products has revealed new biochemical pathways and molecular targets for pharmacological intervention. A leptin anti-idiotype may be useful as a tool in this progress and future studies may demonstrate a benefit in obese individuals with normal to low leptin levels as well as those dieters wishing to prevent or diminish the rebound effect.

\section{Acknowledgments}

This work was funded by Linea Especial Investigación, University of Navarra and the Government of Navarra (Department of Health).

\section{References}

1. Bray GA. Obesity-a disease of nutrient or energy balance? Nutr Rev. 1987;45:33-43.

2. Pan Y, Yuhasz SC, Amzel LM. Anti-idiotypic antibodies: biological function and structural studies. FASEB J. 1995;9: 43-9.

3. Briones-Urbina R, Islam MN, Ivanyi J, Farid NR. Use of anti-idiotypic antibodies as probes for the interaction of TSH subunits with its receptor. J Cell Biochem. 1987;34:151-62.

4. Tavares L, Roneker C, Postie L, Fevereiro M, de Noronha F. Anti-idiotypic antibodies to feline leukemia virus: an approach for retroviral immunization strategies. Viral Immunol. 1991;4:5-16.

5. Reilly TM, Root RT. Production of idiotypic and anti-idiotypic antibodies by BALB/c mice in response to immunizations with glucagon, vasopressin, or insulin: supporting evidence for the network concept. J Immunol. 1986;137:597602.

6. Grasso P, Leinung MC, Ingher SP, Lee DW. In vivo effects of leptin-related synthetic peptides on body weight and food intake in female ob/ob mice: localization of leptin activity to domains between amino acid residues 106-140. Endocrinology. 1997;138:1413-8.

7. Martínez-Ansó E, Perez M, Martínez JA. Induction of hypothermia, hypoglycemia and hyperinsulinemia after acute leptin immunoneutralization in overnight fasted mice. Int $J$ Mol Med. 1998;2:681-3.

8. Frederich RC, Lollmann B, Hamann A, et al. Expression of ob mRNA and its encoded protein in rodents. Impact of nutrition and obesity. J Clin Invest. 1995;96:1658-63.

9. Baskin DG, Figlewicz Lattemann D, Seeley RJ, Woods SC, Porte D Jr, Schwartz MW. Insulin and leptin: dual adiposity signals to the brain for the regulation of food intake and body weight. Brain Res. 1999;848:114-23.

10. Halaas JL, Gajiwala KS, Maffei M, et al. Weight-reducing effects of the plasma protein encoded by the obese gene. Science. 1995;269:543-6.

11. Haynes WG, Morgan DA, Walsh SA, Mark AL, Sivitz WI. Receptor-mediated regional sympathetic nerve activation by leptin. J Clin Invest. 1997;100:270-8.
12. Maffei M, Halaas J, Ravussin E, et al. Leptin levels in human and rodent: measurement of plasma leptin and ob RNA in obese and weight-reduced subjects. Nat Med. 1995;1: 1155-61.

13. Heymsfield SB, Greenberg AS, Fujioka K, et al. Recombinant leptin for weight loss in obese and lean adults: a randomized, controlled, dose-escalation trial. J Am Med Assoc. 1999; 282:1568-75.

14. Considine RV, Sinha MK, Heiman ML, et al. Serum immunoreactive-leptin concentrations in normal-weight and obese humans. N Engl J Med. 1996;334:292-5.

15. Farooqi IS, Keogh JM, Kamath S, et al. Partial leptin deficiency and human adiposity. Nature. 2001;414:34-5.

16. Keim NL, Stern JS, Havel PJ. Relation between circulating leptin concentrations and appetite during a prolonged, moderate energy deficit in women. Am J Clin Nutr. 1998;68:794801.

17. Farooqi IS, Jebb SA, Langmack G, et al. Effects of recombinant leptin therapy in a child with congenital leptin deficiency. N Engl J Med. 1999;341:879-84.

18. Paxinos G, Watson C. The Rat Brain in Stereotaxic Coordinates. San Diego, CA: Academic Press; 1997.

19. Sarobe P, Lasarte JJ, Golvano J, et al. Induction of antibodies against a peptide hapten does not require covalent linkage between the hapten and a class II presentable T helper peptide. Eur J Immunol. 1991;21:1555-8.

20. Martinez-Anso E, Castillo JE, Diez J, Medina JF, Prieto J. Immunohistochemical detection of chloride/bicarbonate anion exchangers in human liver. Hepatology. 1994;19:1400-6.

21. Wang BS, Zhang RJ, Bona CA, Moran TM. Promotion of animal growth with a monoclonal anti-idiotype specific to anti-porcine growth hormone antibody. Mol Immunol. 1994; 31:651-6.

22. Flint DJ. Effects of antibodies to adipocytes on body weight, food intake, and adipose tissue cellularity in obese rats. Biochem Biophys Res Commun. 1998;252:263-8.

23. Zhang Y, Proenca R, Maffei M, Barone M, Leopold L, Friedman JM. Positional cloning of the mouse obese gene and its human homologue. Nature. 1994;372:425-32.

24. Campfield LA, Smith FJ, Guisez Y, Devos R, Burn P. Recombinant mouse OB protein: evidence for a peripheral signal linking adiposity and central neural networks. Science. 1995;269:546-9.

25. Pelleymounter MA, Cullen MJ, Baker MB, et al. Effects of the obese gene product on body weight regulation in ob/ob mice. Science. 1995;269:540-3.

26. Frederich RC, Hamann A, Anderson S, Lollmann B, Lowell BB, Flier JS. Leptin levels reflect body lipid content in mice: evidence for diet- induced resistance to leptin action. Nat Med. 1995;1:1311-4.

27. Isaacs JD, Watts RA, Hazleman BL, et al. Humanised monoclonal antibody therapy for rheumatoid arthritis. Lancet. 1992;340:748-52.

28. Banks WA, Kastin AJ, Huang W, Jaspan JB, Maness LM. Leptin enters the brain by a saturable system independent of insulin. Peptides. 1996;17:305-11. 